\title{
Is perioperative pro-B-type natriuretic peptide a good tool to evaluate surgical risk in cardiac surgery?
}

Marta Matamala*, Neslim Gálvez, Elisa Ochoa, Ana Barral, Javier Fañanás, Jose María Vallejo, Manuel Vázquez, Fernando Sorribas, Carlos Ballester

From World Society of Cardiothoracic Surgeons 25th Anniversary Congress, Edinburgh Edinburgh, UK. 19-22 September 2015

\section{Background/Introduction}

Predicting major adverse events and death in patients undergoing cardiac surgery is based on clinical risk scores such as Euroscore. This score has a moderate power for discriminating morbidity. Natriuretic peptides are wellestablished biomarkers in numerous clinical settings, prognostic, diagnostic and treatment of cardiac failure. In cardiac surgical patients the role of natriuretic peptides as risk markers is less well delineated.

\section{Aims/Objectives}

To assess the utility of natriuretic peptides as risk markers in cardiac surgery

\section{Method}

This study is a prospective longitudinal study of consecutive 135 patients undergoing on-pump cardiac surgery between 2012 and 2013. We evaluated preoperative euroSCORE II, preoperative and $24 \mathrm{~h}$ postoperative pro-BNP. The endpoints were: heart failure, renal failure, all-cause mortality at 12 months. Independent sample t-Test were performed.

\section{Results}

One hundred thirty-five patients were available for analysis. the mean EuroSCORE II was 2,49\%. Fourteen patients (10\%) experienced postoperative heart failure and 30 patients $(22 \%)$ renal failure. Within 12 months after surgery, six patients died. The " $t$ " test showed significant augmentation of preoperative and postoperative pro-BNP in relation to heart and kidney failure.

\footnotetext{
Left a Servicio de Cirugía Cardiovascular, Hospital Universitario Miguel Servet,
} Zaragoza, Spain

Submit your next manuscript to BioMed Central and take full advantage of:

- Convenient online submission

- Thorough peer review

- No space constraints or color figure charges

- Immediate publication on acceptance

- Inclusion in PubMed, CAS, Scopus and Google Scholar

- Research which is freely available for redistribution 